\begin{tabular}{|c|l|}
\hline Title & Windthrow resistance of apple trees grafted in an orchard \\
\hline Author(s) & Koizumi, A kio; A raki, Hajime; Hori, Hirotaka; Inagawa, Y utaka \\
\hline Citation & $\begin{array}{l}\text { Journal of Wood Science, 54(1), 10-15 } \\
\text { https://doi.org/10.1007/310086-007-0907-7 }\end{array}$ \\
\hline Issue Date & 2008-01 \\
\hline Doc URL & http://hdl.handle.net/2115/32604 \\
\hline Rights & The original publication is available at www.springerlink.com \\
\hline Type & article (author version) \\
\hline File Information & koizumi.pdf \\
\hline
\end{tabular}

Instructions for use 


\title{
Windthrow resistance of apple trees grafted in an orchard
}

\author{
By \\ Akio Koizumi (Graduate school of Agriculture, Hokkaido University), \\ Hajime Araki (Field Science Center for Northern Biosphere, Hokkaido University) \\ Hirotaka Hori (Yoichi Orchard, Hokkaido University) \\ Yutaka Inagawa (Fruit Tree Section, Hokkaido Central Agricultural Experiment Station)
}

\begin{abstract}
Pull-down tests were conducted for apple trees grafted in an orchard and for support posts in order to discuss the failure mode in windthrow damage, the effect of rootstock types on the uprooting strength, and the reinforcing effect of support posts on young trees. The test samples were 10 mature trees (20-23 years old) of 3 varieties grafted on two types of rootstocks, 3 young trees ( 7 years old) grafted on dwarf rootstocks, and 9 support posts of larch logs and steel pipes. The failure modes were found to be uprooting for mature trees and rootstock breakage for young trees. The uprooting strength of apple trees was considerably smaller than the uprooting strength of forest trees reported in previous studies. However, the windthrow resistance of the apple trees with respect to the critical wind velocity was estimated to be sufficient despite their low uprooting strength because of their small height. Young trees should be supported with wooden posts for a few years after grafting so that they acquire sufficient windthrow resistance.
\end{abstract}

Keywords: windthrow resistance, critical wind velocity, uprooting strength, apple trees, pull-down test

\section{Introduction}

In 2004, Japan faced a record number of ten typhoon attacks that resulted in severe windthrow damage to both plantations and park trees. Apple trees planted in orchards in Hokkaido also suffered considerable damage by typhoons 0415 and 0418, and the damaged area extended to 666 ha in Hokkaido ${ }^{1}$. Although most of the damage to apple trees was in the form of fruit drop, uprooting of mature trees and stem break of young trees were also observed.

Yamamoto $^{2}$ analyzed the windthrow susceptibility for orchard trees by assuming the tree to be a cantilever beam supported at the ground level and on the basis of experimental data for the strength of stems and roots. The drag coefficients for the tree crowns were estimated from a wind tunnel study conducted on small models. Although pull-down tests are necessary to evaluate the uprooting strength of trees, the experimental data have been limited to forest trees heretofore. The pull-down test results for forest trees ${ }^{3-6}$ suggest that there are considerable differences among species and among soil conditions. In this study, the windthrow resistance of apple trees is discussed based on pull-down tests. The effects of the rootstock types on which apple scions are grafted and of support posts on young trees are also discussed.

\section{Materials and methods}

Sample trees

Thirteen apple trees (Malus domestica) grafted on two kinds of rootstocks in the Yoichi Orchard of the Field Science Center for Northern Biosphere, Hokkaido University were sampled. The tested rootstocks were marubakaido (Malus prunifolia var. ringo) and the dwarf rootstock of M.26. The ages of the sample trees after grafting were 20-23 years for mature trees and 7 years for young trees. The tree height, crown height, crown diameter, breast height diameter, and stem diameter at the ground level were measured before the pull-down tests (Table 1).

Support post specimens

Usually, young apple trees are supported by a single post comprising a log or a steel pipe. Six larch logs of approximately $10 \mathrm{~cm}$ in diameter (PG post) and three steel pipes with an outer diameter of $35 \mathrm{~mm}$ and a pipe wall 
thickness of $2 \mathrm{~mm}$ were used in the pull-down tests. The post specimens were embedded approximately $1 \mathrm{~m}$ into the ground before the tests.

\section{Pull-down test}

The Pull-down tests were conducted by pulling a load sling strapped to a stem at a lower position of the crown with a hand winch (capacity: $29 \mathrm{kN}$ ) until the tree failed by uprooting or stem break (Fig. 1). The heights of the load slings were $170 \mathrm{~cm}$ for tree nos. 1-10 and $120 \mathrm{~cm}$ for tree nos. 11-13. The load slings for the support posts were strapped at a height of $120 \mathrm{~cm}$ at which the young trees were bound to the posts. The tensile loads were detected with a load cell connected between the load sling and a wire. The moment at the tree base $\left(M_{\mathrm{R}}\right)$ was calculated by Eq. 1 .

$$
M_{\mathrm{R}}=P \cos \theta_{\mathrm{L}} H_{\mathrm{L}}
$$

where, $P$ denotes the tensile load; $\theta_{\mathrm{L}}$, the load angle; and $H_{\mathrm{L}}$, the height of the load.

The horizontal displacement of the reference point set on the stem was measured with a transit placed a few meters distance from the sample tree. The heights of the reference points were $140 \mathrm{~cm}$ for tree nos. 1-10 and 120 $\mathrm{cm}$ for tree nos. 11-13 and the support posts. The rotation angles of the sample trees were calculated from the horizontal displacement, which includes the bending deflection of the stem, assuming the rotation center lies at the ground level.

Dimensions of root plates

After the pull-down tests, the height of root-plate rise $\left(H_{\mathrm{R}}\right)$ and the depth $\left(D_{\mathrm{R}}\right)$ and breadth $\left(B_{\mathrm{R}}\right)$ of the root plate were measured (see Fig. 2). The area $\left(A_{\mathrm{R}}\right)$, volume $\left(V_{\mathrm{R}}\right)$ of the root plate (assuming the root plate as a hemi-ellipsoid whose three radii are $B_{\mathrm{R}} / 2, D_{\mathrm{R}}$, and $H_{\mathrm{R}}$ ) and the geometrical moment of the uprooted area of an ellipse-shaped root-plate $\left(G_{\mathrm{R}}\right)$ were calculated from Eqs. 2-4 as indices to the moment resistance of the root plates since the uprooting moment is expected to be positively proportional to the dimensions of the root plate ${ }^{8}$.

$$
\begin{aligned}
& A_{\mathrm{R}}=\frac{\pi H_{\mathrm{R}} B_{\mathrm{R}}}{2} \\
& V_{\mathrm{R}}=\frac{\pi H_{\mathrm{R}} B_{\mathrm{R}} D_{\mathrm{R}}}{3} \\
& G_{\mathrm{R}}=\frac{H_{\mathrm{R}}^{2} B_{\mathrm{R}}}{3}
\end{aligned}
$$

The uprooting mechanism has been explained as a shear slip at the boundary surface between the root bowl and the soil in the case of deep-rooted trees and the over-turn failure of a thin root plate, which is initiated by the tensile failure of the windward side of the root plate in the case of shallow-rooted trees ${ }^{9}$. In the former case, the uprooting resistance may be proportional to $A_{\mathrm{R}}$ or $V_{\mathrm{R}}$. In the latter case, the amount of tensile stresses acting on the windward side of the root plate is proportional to the distance from the rotation center of the root plate. By assuming that the rotation center lies at the ground level along the stem line, the uprooting moment may be proportional to the geometrical moment of area for the windward side of the root plate $\left(G_{\mathrm{R}}\right)^{8}$.

Density of rootstock wood and strength of stem wood

The specimens for wood density were cut from the horizontal-root ends of tree nos. 1-10, where tensile fracture occurred during uprooting. The density specimens for tree nos. 11-13 were cut from both the rootstock sides and scion sides of the grafted sections and at the breast height position of each tree.

Thirty-centimeter-long logs were cut from tree nos. 1-10, corresponding to the part 90-120 cm above the ground level. Each log was quarter sawn to obtain 30-mm-thick unedged planks, including piths. Twenty small, clear specimens with a cross section of $20 \times 20 \mathrm{~mm}^{2}$ and a length of $300 \mathrm{~mm}$ were cut from both the outer sides of the ten air-dried planks and the modulus of elasticity $(M O E)$, bending strength $(M O R)$, and compressive strength parallel to the grain $(C S)$ were measured. The average moisture content of the specimens was $12.7 \%$.

Estimation of critical wind velocity

By assuming the trees to be cantilever beams fixed at the ground level, the moment at the ground level $\left(M_{\mathrm{R}}\right)$ 
induced by a wind force acting on the crown is expressed by Eq. 5 .

$$
M_{\mathrm{R}}=\frac{1}{2} C_{\mathrm{D}} \rho v^{2} A H_{\mathrm{W}}
$$

where, $C_{\mathrm{D}}$ denotes the drag coefficient of the tree crown; $\rho$, the air density $\left(1.20 \mathrm{~kg} / \mathrm{m}^{3}\right) ; v$, the wind velocity; $A$, the horizontally projected crown area; and $H_{\mathrm{W}}$, the height of the wind pressure center.

By assuming the horizontally projected shape of the crown to be an ellipse, the height of the wind pressure center is half the crown length above the crown height. Subsequently, the critical wind velocity $\left(v_{\mathrm{c}}\right)$ that causes uprooting or stem break at the ground level is calculated by Eq. 6 as follows:

$$
v_{\mathrm{c}}=4 \sqrt{\frac{M_{\max }}{C_{\mathrm{D}} \rho \pi D_{\mathrm{C}}\left(H^{2}-H_{\mathrm{C}}{ }^{2}\right)}}
$$

where, $M_{\max }$ denotes the maximum moment at the tree base observed in the pull-down tests; $D_{\mathrm{C}}$, the crown diameter; $H$, the tree height; and $H_{\mathrm{C}}$, the crown height.

\section{Results and discussion}

The failure modes observed in the pull-down tests were classified into two modes-uprooting for mature trees (nos. 1-10) and bending failure at the ground level for young trees (nos. 11-13)

\section{Uprooting failure for mature trees}

The Moment-rotation angle relationships were almost linear at low stress levels. Further, the root systems gradually yielded as the load increased and reached the maximum load when the horizontal roots at the edge of the tension side of the root plates fractured with a snapping sound (Figs. 3, 4). The uprooting moment of the marubakaido rootstock was greater than those of M.26 at the significance level of $5 \%$ (Fig. 5). Although the correlations between the root plate dimensions $\left(A_{\mathrm{R}}, V_{\mathrm{R}}\right.$, and $\left.G_{\mathrm{R}}\right)$ and the maximum moment $\left(M_{\max }\right)$ were not high, the root plate dimensions of marubakaido were greater than those of M.26 (Fig. 6). The results suggested that the apple trees grafted on M.26 were susceptible to uprooting damage because of their less-developed root plate.

The power function of the breast height diameter $\left(D_{\mathrm{B}}\right)$ curve-fitted to the $M_{\max }-D_{\mathrm{B}}$ relationship was compared with the power functions reported in previous studies (Fig. 7). The thick lines and filled circle (sites b, d, h, and i) are the results for broad-leaved species. The thin broken line (site e) represents coniferous plantations on soils of volcanic origin ${ }^{5}$. Although the trends show that the uprooting moments of broad-leaved trees are greater than those of conifers for identical sites, the uprooting moments considerably vary among the sites and species. The uprooting moments of the apple trees (site i) are considerably smaller than those for other sites and species. The reason might be attributed to the poorly developed root plates and the cultivation treatment.

An adequate correlation was observed between the initial stiffness and the uprooting moment, where the initial stiffness was defined as the slope of a regression line fitted to the moment-deflection angle data shown in Fig. 3 in the range from $0.1 M_{\max }$ to $0.4 M_{\max }$ (Fig. 8). Although the component of bending deflection of the trunk is not subtracted from the observed horizontal displacement, the uprooting moment could be estimated nondestructively from the tree bending tests, provided the tests were conducted for the trees of similar age and from the same orchard.

\section{Breakage of rootstock for young trees}

All trees with an age of 7 years after grafting (nos. 11-13) broke at the rootstock side of the grafted section of the stems. The failure mode was brittle fracture caused by the bending moment. The average MOR at the broken positions was calculated as 9.43 MPa. The average MOR for small, clear specimens cut from the breast height section of the trunks was 77.5 MPa for air-dry conditions (Table 2). The average bulk density (oven-dry weight/green volume) for the M.26 rootstock of tree nos. $11-13$ was $689 \mathrm{~kg} / \mathrm{m}^{3}$, which is greater than the average bulk densities of stem wood near the grafted position $\left(656 \mathrm{~kg} / \mathrm{m}^{3}\right)$ and of stem wood at the breast height position $\left(542 \mathrm{~kg} / \mathrm{m}^{3}\right)$. The reason why the MOR of rootstock was considerably less than that of trunk wood could be the anatomical characteristics of the root tissue, such as fiber length. The insufficient radial growth of rootstock a few years after grafting might lead to the breakage of the rootstock. 
The maximum moment at the ground level $\left(M_{\max }\right.$, unit: $\left.\mathrm{kNm}\right)$ for young trees can be expressed by Eq. 7 , assuming the MOR to be $9.43 \mathrm{MPa}$.

$$
M_{\text {max }}=\frac{9430 \pi D_{0}^{3}}{32}
$$

where, $D_{0}$ denotes the xylem diameter in meters at the ground level.

By comparing the function in Eq. 7 with the regression function of $D_{0}$ for the uprooting strength of mature trees, it is expected that the failure mode for grafted trees changes from rootstock breakage to uprooting as $D_{0}$ increases (Fig. 9).

Apple trees are supported by wooden or steel pipe posts for several years after grafting. In the pull-down tests, it was observed that the larch-wood posts broke at the ground level due to an average bending moment of 2.77 $\mathrm{kNm}$. Consequently, the average MOR of larch-logs was calculated as $32.4 \mathrm{MPa}$. On the other hand, the steel pipe post yielded at the ground level due to a bending moment of $737 \mathrm{Nm}$, which was considerably lesser than that for larch-wood posts. By superimposing the moment-deflection curves on those for tree nos. 11-13, the average reinforcing effects of wooden posts and steel pipes for tree nos. 11-13 were estimated as $447 \%$ and $198 \%$, respectively (Fig. 10).

\section{Critical wind velocity}

The critical wind velocities $\left(v_{\mathrm{c}}\right)$ for the tested trees were estimated from Eq. 6, assuming $C_{\mathrm{D}}$ to be 0.2 , which corresponds to that for western hemlock (Tsuga heterophylla) at a wind velocity of $30 \mathrm{~m} / \mathrm{s}$ evaluated from a study of actual-size wind tunnel ${ }^{10}$. Although $C_{\mathrm{D}}$ at a wind velocity of $30 \mathrm{~m} / \mathrm{s}$, evaluated in the study by considering 7 coniferous species, ranged from 0.2 to 0.6 , the smallest value was chosen by considering the thin crown of apple trees and the dense crown of coniferous species.

The estimated $v_{\mathrm{c}}$ for mature trees, which had a breast height diameter of $20 \mathrm{~cm}$ or more, exceeded $40 \mathrm{~m} / \mathrm{s}$ and showed sufficient resistance to wind force (Fig. 11). The reason for high $v_{\mathrm{c}}$ despite a low uprooting strength was the tree form of low crowns. Although the trees grafted on dwarf stocks (M.26) showed lower uprooting strength as compared to those grafted on marubakaido stocks, no difference in $v_{\mathrm{c}}$ was observed.

The estimated values of $v_{\mathrm{c}}$ for young trees (nos. 11-13) were as low as $20-30 \mathrm{~m} / \mathrm{s}$. The windthrow resistance of tree nos. 11-13 could be improved by support posts. The estimated $v_{\mathrm{c}}$ values for the trees supported with a larch-wood post were $50 \mathrm{~m} / \mathrm{s}$, which were equivalent to those for mature trees.

\section{Conclusions}

The windthrow resistance of grafted apple trees was discussed based on pull-down tests. The conclusions obtained are as follows:

1. The windthrow failure modes for grafted apple trees were classified into two-uprooting for mature trees and rootstock breakage at the tree base for young trees. The failure mode was expected to change from rootstock breakage mode to the uprooting mode with an increase in the tree-base diameter.

2. The uprooting strength of apple trees, particularly for those grafted on dwarf rootstocks (M.26), was considerably smaller than the uprooting strengths for other tree species reported in previous studies, due to their poorly developed root system.

3. The windthrow resistance with respect to the critical wind velocity for mature apple trees was considered to be sufficient despite a low uprooting strength. This may be attributed to low tree form. No difference was observed in the critical wind velocities between M.26 and the marubakaido rootstocks.

4. Young trees broke at the tree base a few years after grafting due to the insufficient radial growth of rootstocks. The windthrow resistance of these trees could be increased to that of mature trees by supporting them with wooden posts.

\section{Acknowledgement}

This study was supported in part by a grant-in aid for collaborative research by NOASTEC (No. H17-kyo-048). 


\section{References}

1. Araki H (2006) Analysis on windthrow damage of orchard trees by Typhoon 18 (in Japanese). Report of the grant-in-aid for collaborative research by NOASTEC No.H17-kyo-048: 1-35

2. Yamamoto R (1979) Protection of fruit trees against the strong wind damage (in Japanese). J Agricultural Meteorology 35: 177-187

3. Kamata M (1956) On the strength of the defence forest tree and defence pile (in Japanese). Seppyo 21: 182-185

4. Tamate S, Kashiyama T, Sasanuma T, Takahashi K (1965) A trial of pulling down standing trees (in Japanese). J Japanese Forest Research 47: 210-123

5. Koizumi A (1987) Studies on the estimation of the mechanical properties of standing trees by non-destructive test (in Japanese). Res. Bull. College Experiment Forests 44: 1329-1415

6. Peltola H, Kellomäki S, Hassinen A, Granander M (2000) Mechanical stability of Scots pine, Norway spruce and birch: an analysis of tree-pulling experiments in Finland. Forest Ecology and Management 135: 143-153

7. Masuda T (2005) Cultivation characteristics of dwarf rootstocks for apple trees (in Japanese). Agriculture and horticulture 80: 1081-1091

8. Koizumi A, Oonuma N, Sasaki Y, Takahashi K (2007) Difference in uprooting resistance among coniferous species planted in soils of volcanic origin. J Forest Research 12: 237-242

9. Thomas PA (2000) Trees: their natural history. Cambridge University Press, Cambridge, pp.289

10. Mayhead GJ (1973) Some drag coefficients for British forest trees derived from wind tunnel studies.

Agricultural Meteorology 12: 123-130 
Table 1. Dimensions of sample trees

\begin{tabular}{rllrrrrrr}
\hline No & Rootstock $^{\mathrm{a}}$ & Variety $^{\mathrm{b}}$ & Age (year) & $H(\mathrm{~m})$ & $H_{\mathrm{C}}(\mathrm{m})$ & $D_{\mathrm{C}}(\mathrm{m})$ & $D_{\mathrm{B}}(\mathrm{cm})$ & $D_{0}(\mathrm{~cm})$ \\
\hline 1 & Marubakaido & S & 21 & 4.6 & 1.6 & 5.90 & 22.0 & 25.8 \\
2 & Marubakaido & S & 21 & 4.6 & 1.1 & 6.20 & 22.6 & 26.1 \\
3 & Marubakaido & S & 21 & 4.5 & 1.1 & 5.40 & 25.5 & 36.0 \\
4 & Marubakaido & S & 21 & 3.9 & 1.6 & 5.25 & 22.6 & 25.5 \\
5 & Marubakaido & S & 21 & 5.0 & 1.8 & 5.60 & 20.7 & 27.7 \\
6 & M.26 & GD & 23 & 3.7 & 1.6 & 4.35 & 22.3 & 22.9 \\
7 & M.26 & GD & 21 & 3.5 & 1.5 & 5.15 & 20.7 & 24.5 \\
8 & M.26 & GD & 20 & 4.5 & 1.8 & 5.35 & 23.6 & 33.7 \\
9 & M.26 & RG & 22 & 4.3 & 1.2 & 5.25 & 23.2 & 24.2 \\
10 & M.26 & RG & 22 & 4.3 & 1.2 & 4.50 & 16.6 & 20.7 \\
11 & M.26 & F & 7 & 3.4 & 0.5 & 2.30 & 6.0 & 10.2 \\
12 & M.26 & F & 7 & 3.1 & 0.5 & 2.85 & 5.7 & 11.3 \\
13 & M.26 & F & 7 & 3.1 & 1.0 & 2.75 & 6.7 & 9.9 \\
\hline
\end{tabular}

$H$, tree height; $H_{\mathrm{C}}$, crown height; $D_{\mathrm{C}}$, crown diameter; $D_{\mathrm{B}}$, breast height diameter; $D_{0}$, stem diameter at ground level

${ }^{a}$ Marubakaido, Malus prunifolia var. ringo; M.26, dwarf stock

${ }^{\text {b }}$ S, senshu; GD, golden delicious; RG, red gold; F, rakurakufuji 
Table 2. Mechanical properties of small clear specimens sampled at the breast height of mature trees (variety mean)

\begin{tabular}{|c|c|c|c|c|}
\hline Variety $^{\mathrm{a}}$ & $\begin{array}{c}\text { Specific } \\
\text { gravity }\end{array}$ & $\begin{array}{l}M O E \\
(\mathrm{GPa})\end{array}$ & $\begin{array}{l}M O R \\
(\mathrm{MPa}) \\
\end{array}$ & $\begin{array}{c}C S \\
(\mathrm{MPa})\end{array}$ \\
\hline$S$ & 0.729 & 6.18 & 71.5 & 38.1 \\
\hline GD & 0.728 & 8.12 & 77.2 & 43.3 \\
\hline RG & 0.679 & 8.12 & 84.8 & 42.0 \\
\hline Overall & 0.711 & 7.34 & 77.6 & 40.7 \\
\hline
\end{tabular}

${ }^{\text {a }}$ Variety names are shown in Table 1. 


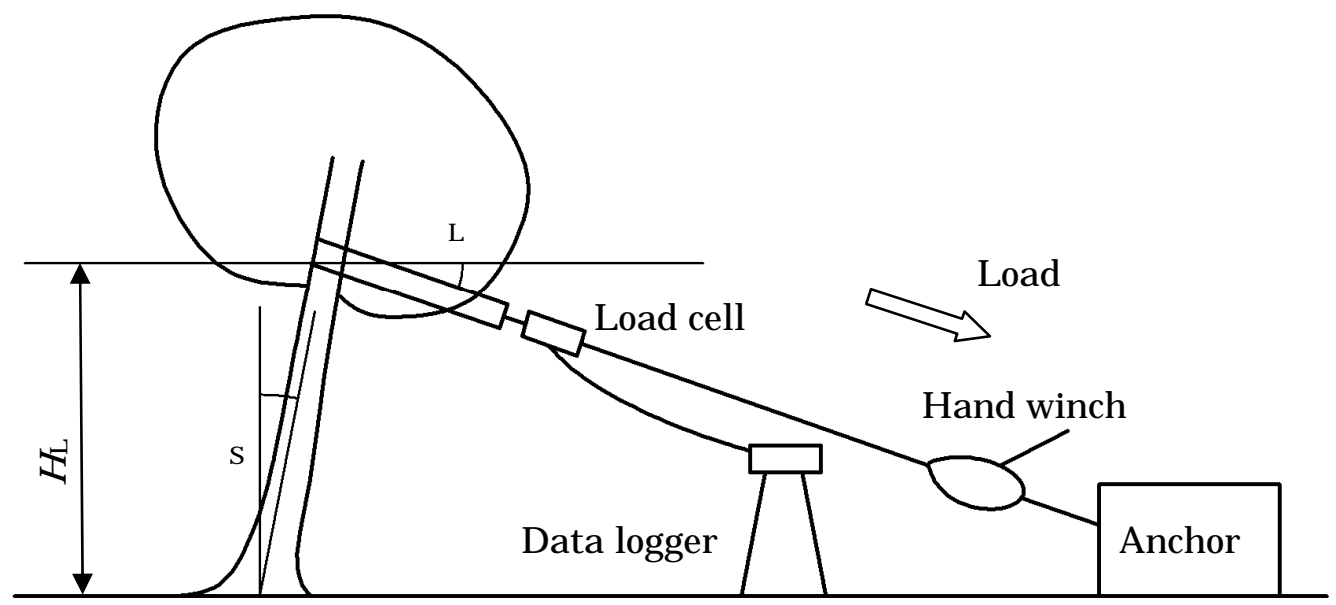

Fig. 1. Schematic diagram of the pull-down test 


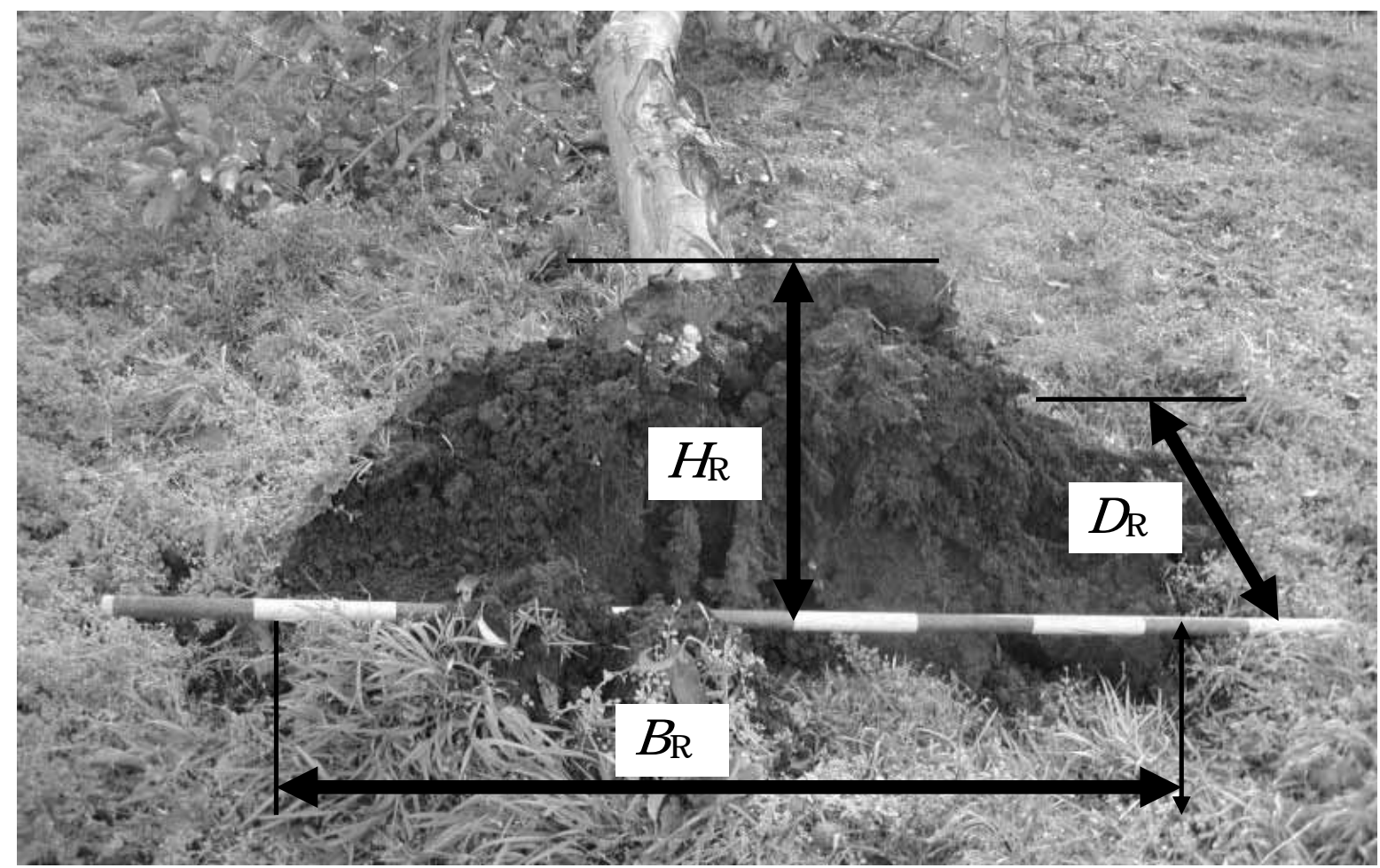

Fig. 2. Dimensions of a root plate measured after uprooting.

$H_{\mathrm{R}}$ is the height of root-plate rise; $D_{\mathrm{R}}$, the depth of the root plate; and $B_{\mathrm{R}}$, the breadth of the root plate 


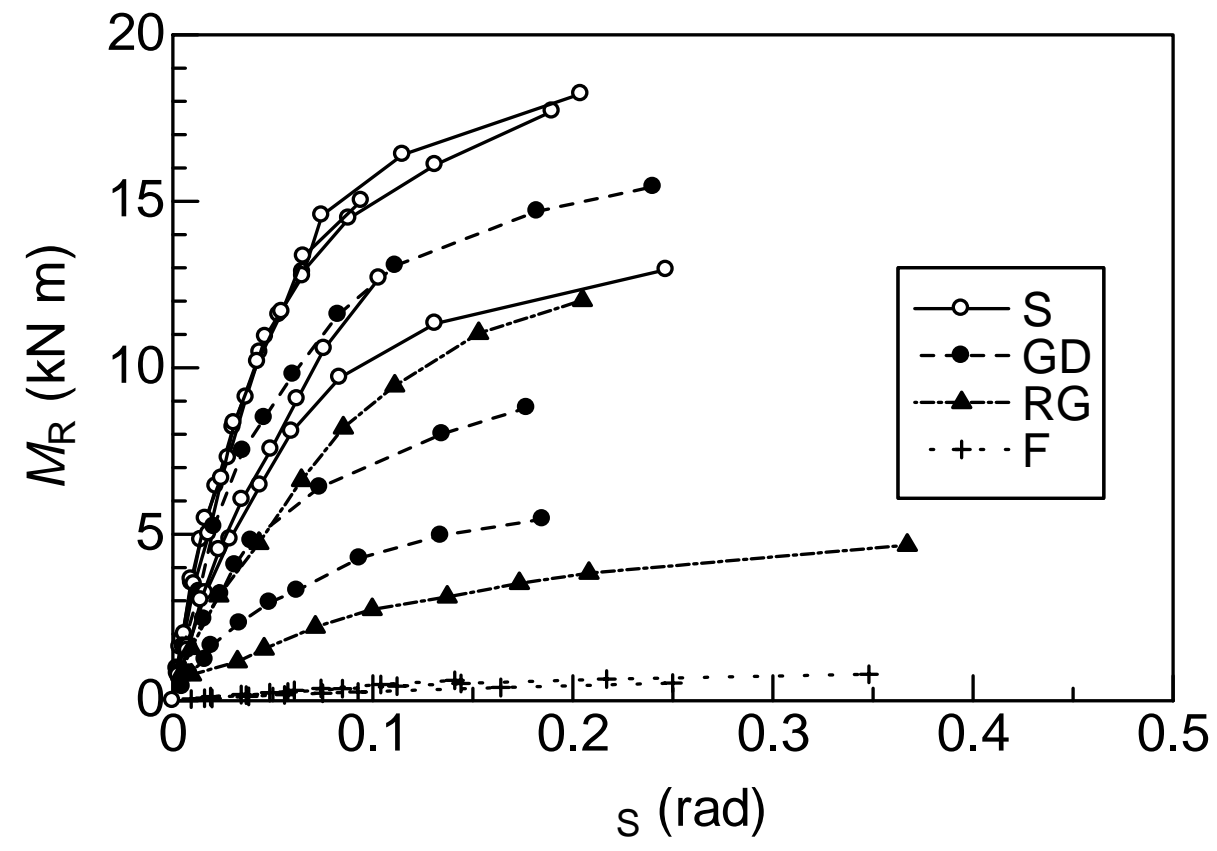

Fig. 3. Moment $\left(M_{\mathrm{R}}\right)$-rotation angle $(\theta \mathrm{s})$ relationships for all sample trees. $S, G D, R G$, and $F$ are the names of the different varieties shown in Table 1. 


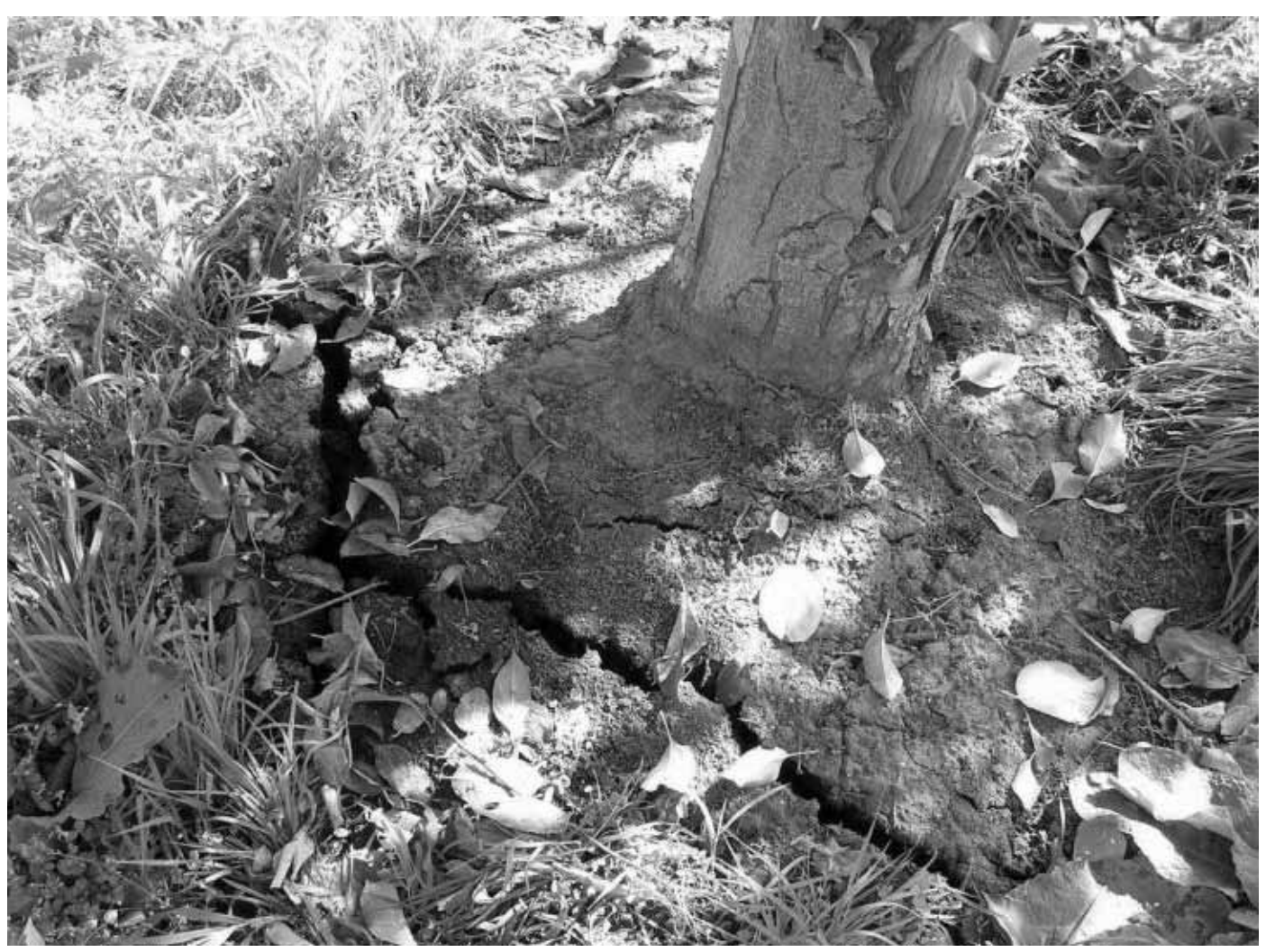

Fig. 4. Uprooting failure initiated by tensile fracture of horizontal roots (tree no. 6) 


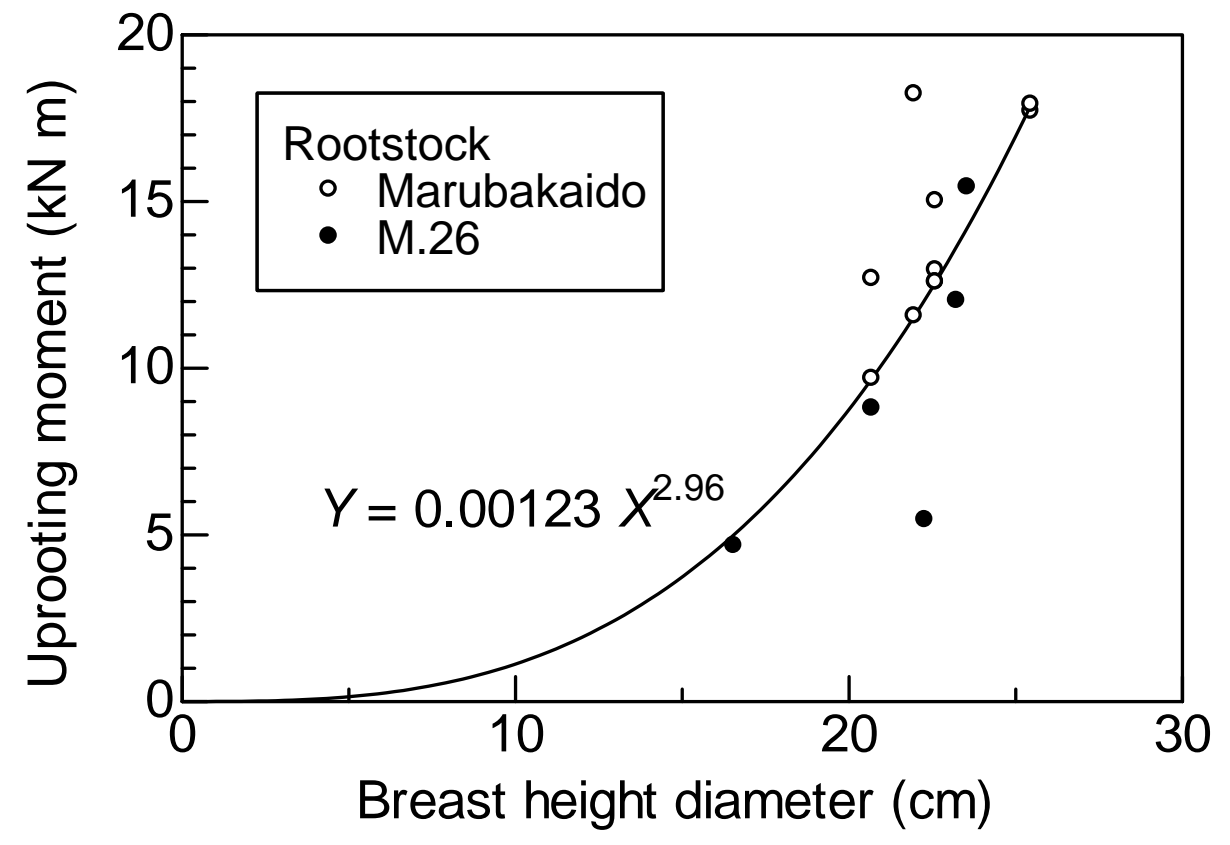

Fig. 5. Uprooting moment as a function of breast height diameter 


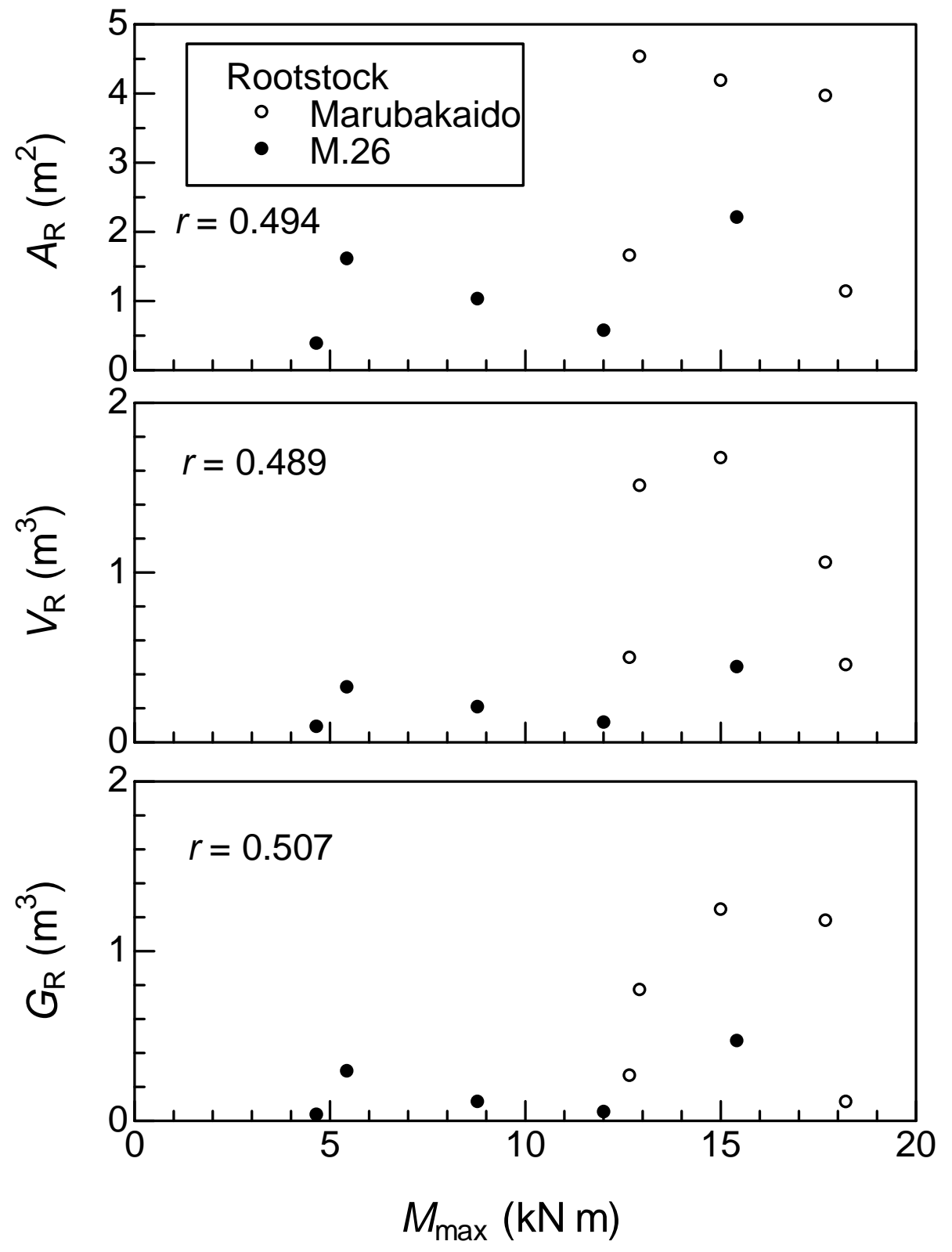

Fig. 6. Relationship between dimensions of root plate and uprooting moment $\left(M_{\max }\right)$ 


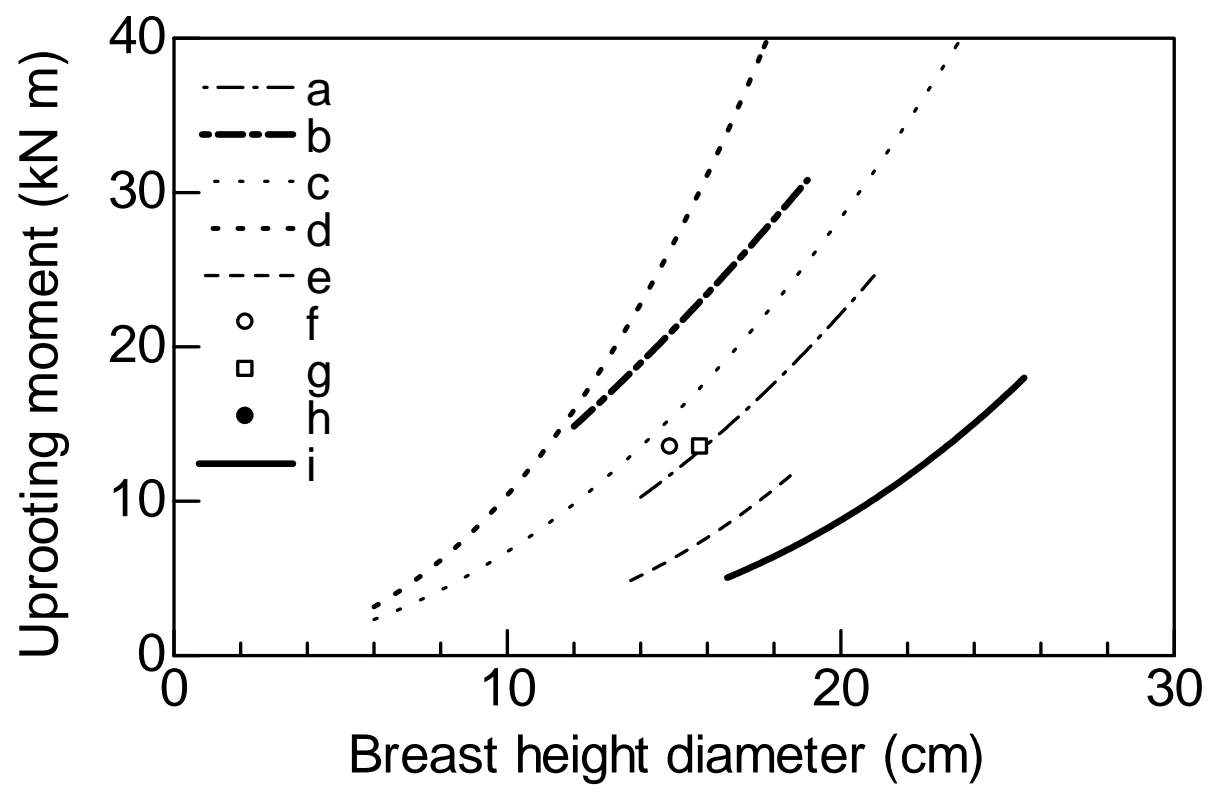

Fig. 7. Comparison of relationship between breast height diameter and uprooting moment observed for various species and sites.

a: sugi (Cryptomeria japonica) and hinoki (Chamaecyparis obtusa) $(n=7)^{4}$;

b: arakashi (Quercus glauca) and kuri (Castanea crenata) $(n=4)^{4}$;

c: sugi $(n=19)^{3}$; d: mizunara (Quercus crispula) and buna (Fagus crenata) $(n=38)^{3}$;

e: todomatsu (Abies sachalinensis), ezomatsu (Picea jezoensis), akaezomatsu (Picea glehnii), and karamatsu (Larix kaempferi) $(n=12)^{5}$; f: Scots pine (Pinus sylvestris) $(n=44)^{6}$; g: Norway spruce (Picea abies) $(n=26)^{6}$; h: birch (Betula spp.) $(n=8)^{6}$; i: this study $(n=10)$ 


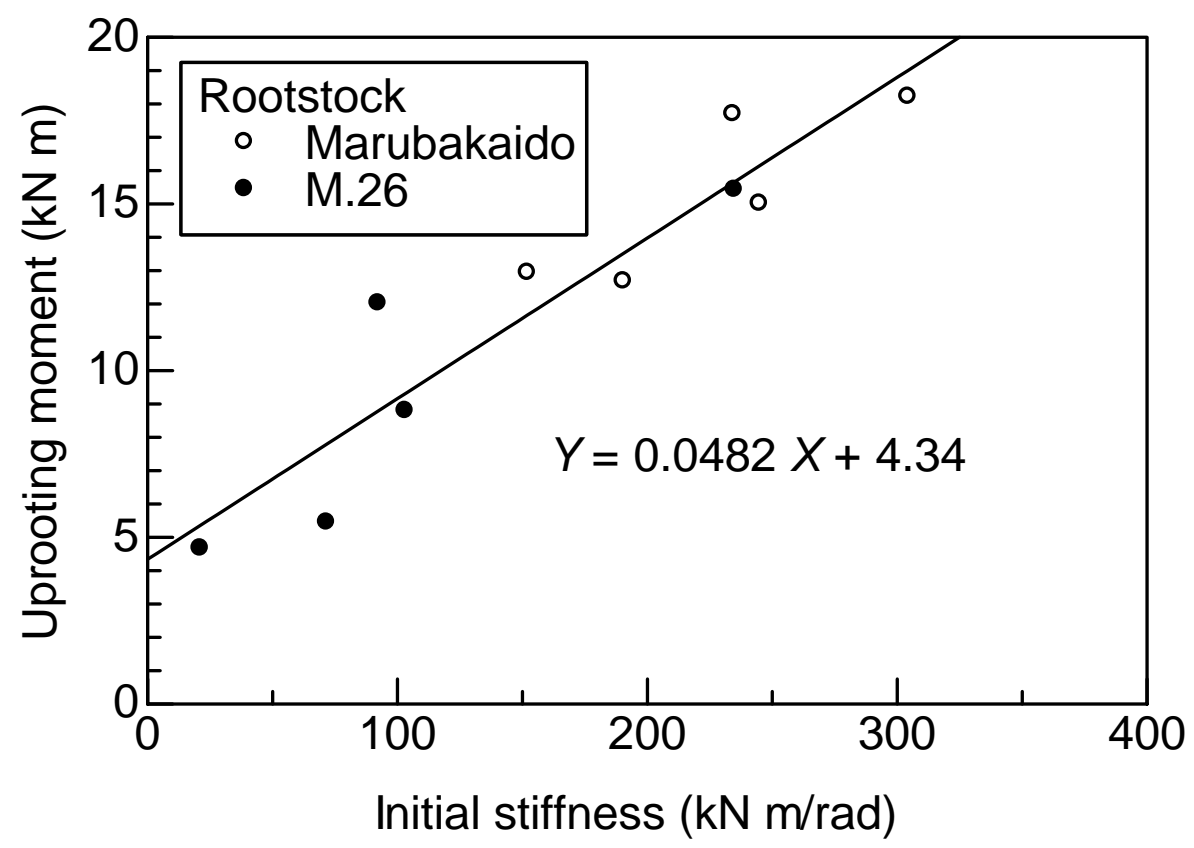

Fig. 8. Correlation between initial stiffness and uprooting moment 


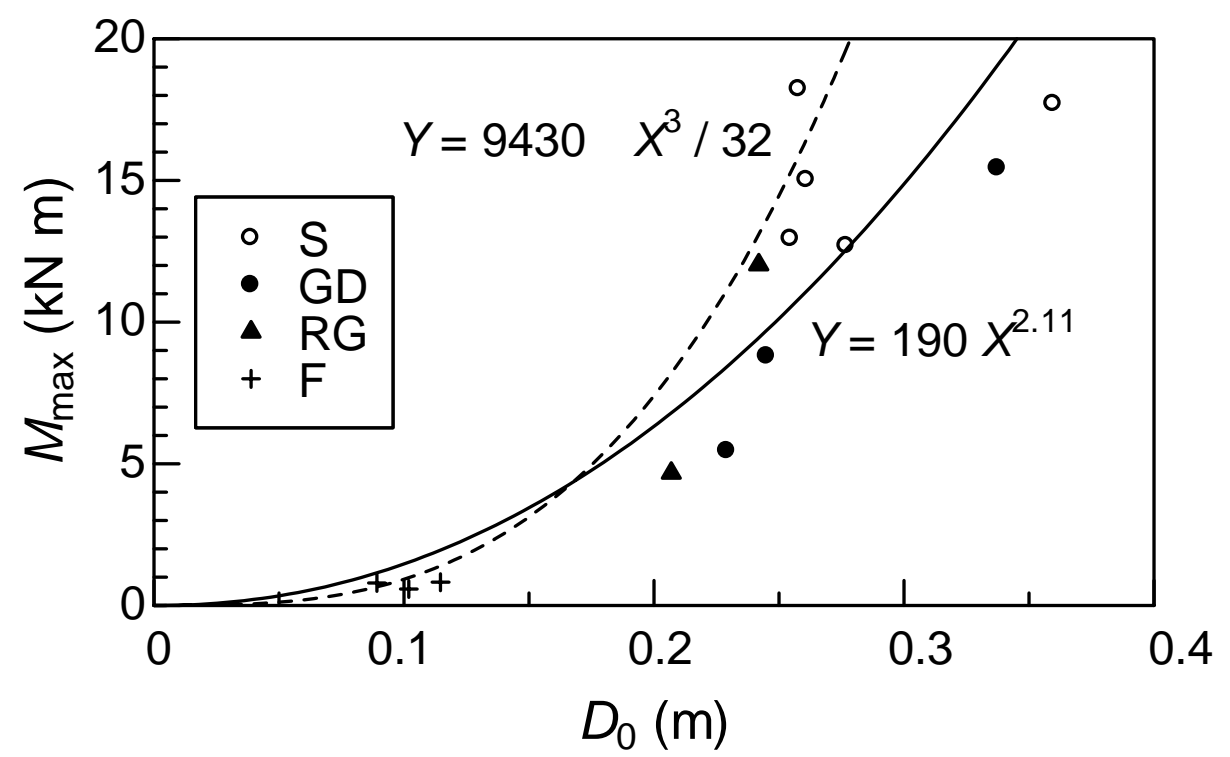

Fig. 9. Maximum moment at tree base $\left(M_{\max }\right)$ as a function of the diameter at ground level $\left(D_{0}\right)$. The broken line is calculated by assuming bending failure at ground level and the solid line is the regression curve for uprooted mature trees.

$\mathrm{S}, \mathrm{GD}, \mathrm{RG}$, and $\mathrm{F}$ are the different varieties shown in Table 1. 


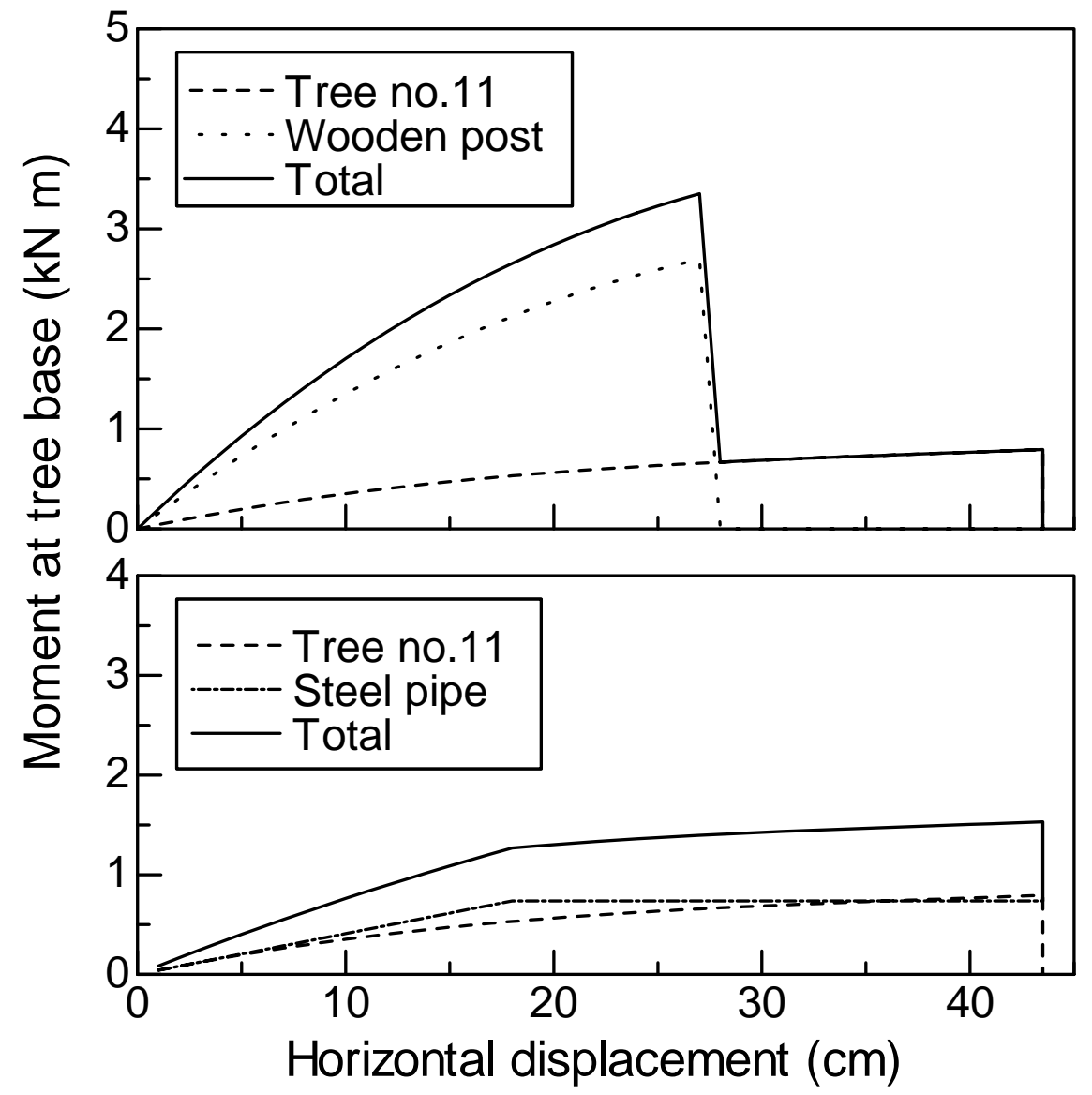

Fig. 10. Relationship between moment at tree base and horizontal displacement at a height of $120 \mathrm{~cm}$ for tree no. 11 with supports of larch-wood posts and steel pipes 


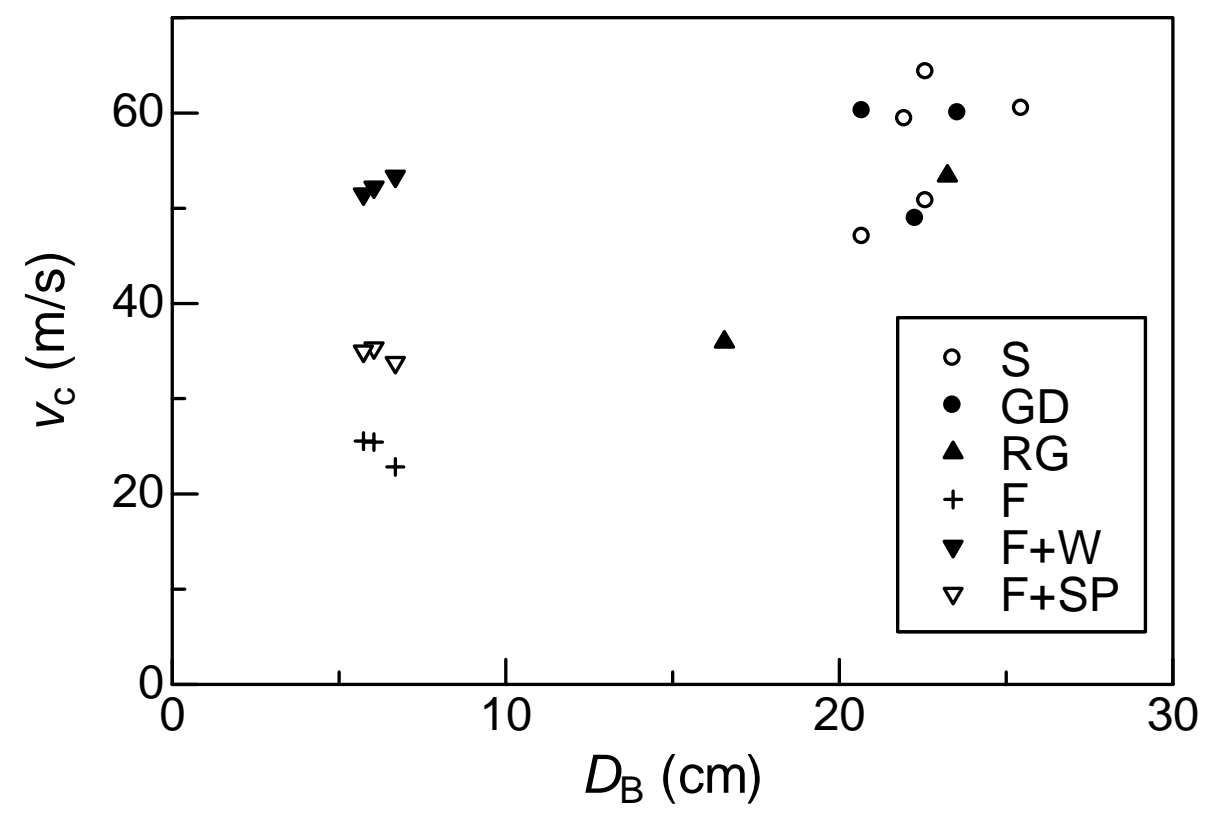

Fig. 11. Relationship between estimated $v_{\mathrm{c}}$ and $D_{\mathrm{B}}$.

S, GD, RG, and F are the different varieties shown in Table 1. F+W and F+SP indicate fuji with a wooden post for support and fuji with a steel pipe for support. 